\title{
EDAFISKO FAKTORU NOZĪME OZOLU PAAUGAS ATTĪSTĪBĀ PRIEŽU EKOSISTĖMĀS RĪGĀ
}

\author{
Vita Amatniece \\ LU G̣eogrāfijas un Zemes zinātṇu fakultāte, e-pasts: vita-amatniece@inbox.lv
}

\begin{abstract}
Anotācija. Latvijas meži atrodas pārejas zonā jeb ekotonā starp nemorālo un boreālo zonu boreonemorālajā starpzonā (Sjörs 1963; Ozenda 1994, Krauklis, Zariṇa 2002), un pēdējās desmitgadēs Latvijā arvien biežāk tiek novērots, ka mežos pazeminās boreālo mežu koku sugu un palielinās nemorālo mežu koku sugu īpatsvars (Laiviņš 1998). Un būtiski būtu noskaidrot, kā edafiskie faktori ietekmē ozolu paaugas attīstībā priežu mežos. Raksta mērķis ir noskaidrot augsnes faktora lomu ozolu paaugas attīstībā priežu mežos Pierīgā. Pētījumā tika konstatēts, ka priežu un bērzu izveidošanos un attīstību ietekmēja $\mathrm{O}$ horizonta biezums un augsnes skābums. Un lai ieviestos un pieaugtu ozols, būtisks ir augstāks pH un slāpekḷa koncentrācija.
\end{abstract}

Atslēgas vārdi: edafiskie faktori, boreonemorālā zona, Pinus sylvestris, Quercus robur, paauga.

Pēdējās desmitgadēs Latvijā, kas atrodas pārejas zonā jeb ekotonā starp nemorālo un boreālo zonu - boreonemorālajā starpzonā (Sjörs 1963; Ozenda 1994; Krauklis, Zariņa 2002), arvien biežāk tiek novērots, ka mežos pazeminās skuju koku sevišķi priedes (boreālo mežu elements), bet pieaug sekundāro lapu koku un, zīmīgi, arī platlapju sugu - ozola, oša, kḷavas, gobas (nemorālo mežu elementi) īpatsvars. Turklāt boreonemorālajā zonā platlapju meži, tajā skaitā ozolu audzes, atrodas sava izplatības areāla ziemeḷu daḷā un tiek uzskatîts, ka temperatūras paaugstināšanās ietekmēs platlapju izplatības areāla palielināšanos, paaugstinot koku sugu daudzveidību, kā tas jau novērots citām sugām ziemeḷu platuma grādos (Garcia-Lopez, Allue 2012; Weber et al. 2008).

Pilsētas mežos priedi jau tagad nomaina citas koku sugas, un tam turpinoties sagaidāma priedes nomaiņa ar citām sugām koku stāvā, visbiežāk tiek prognozēts ar ozolu (Quercus robur L.) dienvidu boreālos mežos un mērenā klimata mežos (Weber et al. 2008; Matias, Jump 2012; Olsson et al. 2013; Laiviņš 1998) un āra bērzu (Betula pendula Roth.) ziemel̦u mežos.

Pētījums tika veikts Vecdaugavas meža masīvā (570 ha) (1. attēls), kas atrodas Rīgas ziemeḷaustrumos.

Pētītajā teritorijā dominējošā suga ir parastā priede (Pinus sylvestris L.), kas veido 88\% no kopējās meža platības un audzes vecums lielākoties ir 80-100 gadi. Pētāmie priežu meži atrodas uz nabadzīgām Arenosol augsnēm. Koku pirmo stāvu veido priede, paaugā gandrīz visos parauglaukumos tika kontstatēts ozols, bieži sastopams arī bērzs.

Kopumā tika apsekoti 23 parauglaukumi pēc nejaušības principa, kas reprezentē pētāmo teritoriju. Apsekotajās vietās tika noteikta veǵetācija un paņemti no nedzīvās zemsegas (O) un virsējā minerālā (Ah vai E, dziḷums $0-10 \mathrm{~cm}$ ) horizonta augsnes paraugi 3 atkārtojumos analīzei laboratorijā. Tika veikta arī ozolu paaugas blīvuma uzskaite visā pētāmajā teritorijā. Kā redzams pēc uzskaites datiem izveidotajā kartē (2. attēls), ozoli paaugā nav sastopami samērā lielā teritorijā - aptuveni pusē no pētāmās teritorijas. 


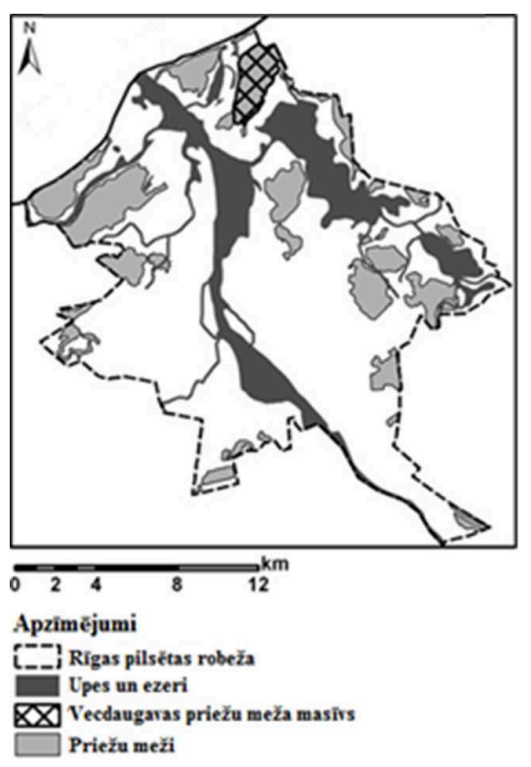

1. attēls. Vecdaugavas meža masīva atrašanās Rīgas pilsētā (izveidojusi Amatniece)

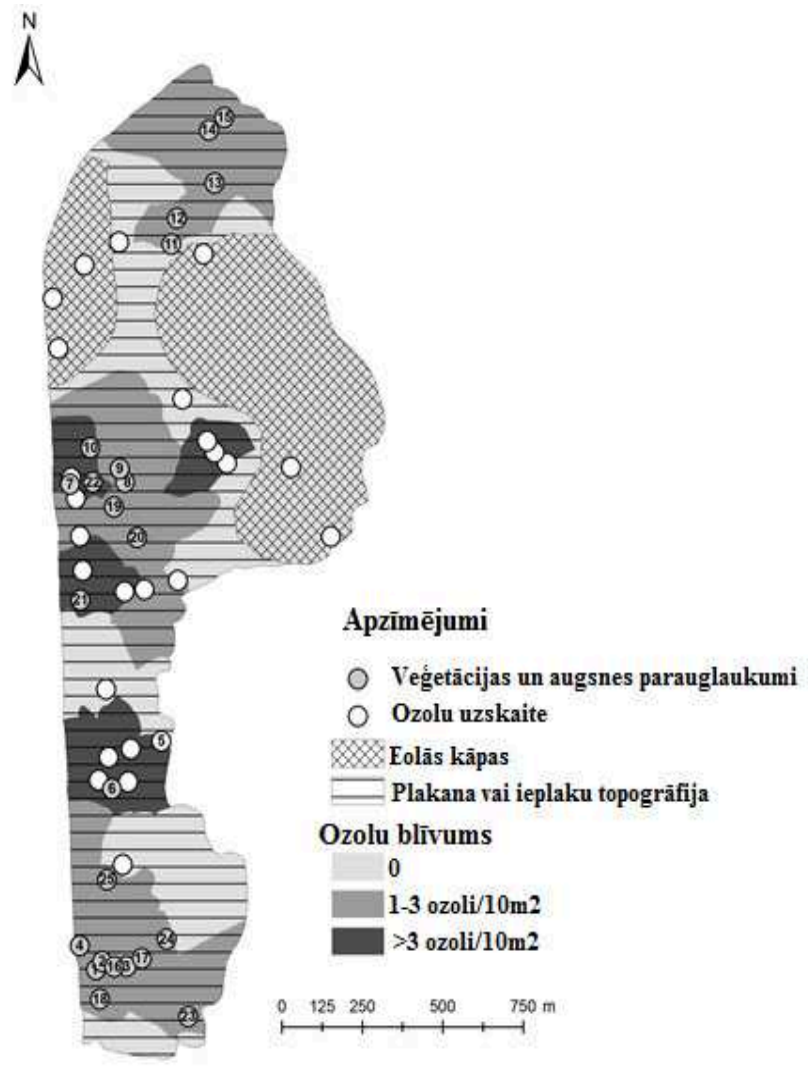

2. attēls. Ozolu blīvums paaugā (izveidojusi Amatniece)

Tika konstatēts, ka vislielākā ozolu izplatība paaugā ir vērojama mitrākās un noēnotākās vietās, ar blīvāku veǵetāciju. Savukārt vietās bez ozoliem paaugā ir izteikti 
mazāks mitrums, vairāk apgaismojums, veǵetācija gan uz zemsedzes, gan augstākos stāvos ir diezgan reta, arī reljefs ir pauguraināks.

Dominējošais augšņu tips pētītajā mežā bija Arenosol uz smilšainiem eolajiem nogulumiem. Augsnēm tika konstatēti vāji attīstījušies horizonti un O horizonta biezums variēja no 0-20 cm, vairāk attīstījies O horizonts tika noteikts ieplakās, kur izveidojies mitrs Moder humuss. O horizontam tika noteikta augsta $\mathrm{C} / \mathrm{N}$ attiecība (virs 35) un vidējais pH bija 3,5. Kopējā slāpekḷa koncentrācija virsējā minerālā horizontā bija zema (vidēji $0,59 \mathrm{mg} \mathrm{g}^{-1}$ ). Relatīvi augstāka organiskā oglekḷa un slāpekḷa koncentrācija, kā arī $\mathrm{Ca}^{2+}$, $\mathrm{Mg}^{2+}, \mathrm{K}^{+}$, katjonu apmaiņas kapacitāte un apmaiṇas skābums bija augstāka O horizontā salīdzinājumā ar virsējo minerālo horizontu rādītājiem.

Pētītajos parauglaukumos augsnes $\mathrm{O}$ horizontā $\mathrm{pH}$ KCl mainījās robežās no 3,0 līdz 4,4 un E horizontā no 3,6 līdz 4,9, analizējot datus kopumā, secināms, ka augsnes ir skābas. Arī augsnes apmaiņas katjonu kapacitātes (KAK, mEq/100g) rezultāti norāda, ka augsne pētītajos priežu mežos ir nabadzīga, attiecīgi, minētais rādītājs O horizontā variē no 2,40 līdz 16,69 un eluviālajā (E) horizontā no 0,46 līdz 1,66.

Pētījumā konstatēts, ka Pierīgā (Vecdaugavas meža masīvā) novērojama tendence, ka nabadzīgā priežu mežaudzes paaugā uz Arenosol smilts augsnēm relatīvi lielās platībās sastopami ozoli. Tika konstatēts, ka priežu un bērzu izveidošanos un attīstību ietekmēja O horizonta biezums un augsnes skābums. Lai arī ozols ir sastopams nabadzīgās augsnēs, pētījums apstiprina tendenci, ka tas vislabāk atjaunojas bāziskās un auglīgās augsnēs ar augstu katjonu apmaiņas kapacitāti. Lai ieviestos un pieaugtu ozols, būtisks ir augstāks pH un slāpekḷa koncentrācija.

\section{Atsauces}

Blaško, R., Högberg, P., Holm Bach, L., Högberg, M.N. (2013). Relations among soil microbial community composition, nitrogen turnover, and tree growth in N-loaded and previously N-loaded boreal spruce forest. Forest Ecology and Management. 302, 319-328.

Diaz-Maroto, I.J., Vila-Lameiro, P. (2008). Pedunculate oak (Quercus robur L.) silviculture in natural stands of NW Spain: Environmental conditioners. Forest Ecology and Management. 256, 702-711.

Garcia-Lopez, J.M., Allue, C. (2012). A phytoclimatic-based indicator for assessing the inherent responsitivity of the European forests to climate change. Ecological Indicators. 18, 73-81.

Gonzalez-Munoz, N., Costa-Tenorio, M., Espigares, T. (2012). Invasion of alien Acacia sealbata on Spanish Quercus robur forests: Impact on soils and vegetation. Forest Ecology and Management. 269, 214-221.

Krauklis, Ā., Zariņa, A. (2002). Parastais skābardis sava areāla ziemeḷu robežas ainavā Latvijā. Ģeogrāfiskie raksti, Folia Geographica X, 16-47.

Laiviņš, M. (1998). Latvijas boreālo priežu mežu sinantropizācija un eitrofikācija. Latvijas veǵetācija. Rīga, Latvijas Universitāte, Bioǵeogrāfijas laboratorija, 137.

Laiviņš, M., Rūsiņa, S. (2007). The dynamics of pine forest vegetation as an indicator of climate change and eutrophication in the integrated monitoring stations in Latvia. Kḷaviňš, M.(eds.) Climate change in Latvia. Latvijas Universitāte, 154-172. 
Matias, L., Jump, A.S. (2012). Interactions between growth, demography and biotic interactions in determining species range limits in a warming world: The case of Pinus sylvestris. Forest Ecology and Management. 282, 10-22.

Olsson, C., Bolmgren, K., Lindström, J., Jönsson, A.M. (2013). Performance of tree phenology models along a bioclimatic gradient in Sweden. Ecological Modelling. 266, 103-117.

Ozenda, P. (1994). Végétation du Continent Européen. Lausanne - Paris, Delachaux et Niestlé, 271.

Sjörs, H. (1963). Amphi-Atlantic zonation, nemoral to Arctic. North Atlantic biota and their history. The Macmillan Company, New York. 109-125.

Stevens, C.J., Dupre, C., Dorland, E., Gaudnik, C., Gowing, D.J.G., Bleeker, A., Diekmann, M., Alard, D., Bobbink, R., Fowler, D., Corcket, E., Mountford, J.O., Vandvik, V., Aarrestad, P.A., Muller, S., Dise, N.B. (2010). Nitrogen deposition threatens species richness of grasslands across Europe. Environmental pollution. 158, 2940-2945.

Weber, P., Rigling, A., Bugmann, H. (2008). Sensitivity of stands dynamics to grazing in mixed Pinus sylvestris and Quercus pubescens forests: A modelling study. 210, 301-311.

\section{Summary}

Forests in Latvia are situated in the transitional zone, or ecotone, between the nemoral and boreal zones - the boreonemoral zone (Sjörs 1963; Ozenda 1994, Krauklis, Zarina 2002). It has been observed that Latvia's forests have seen a decrease in boreal, and an increase in nemoral tree species in the last few decades (Laiviņš 1998). Determining the role of edaphic factors in oak undergrowth development in pine forests would be a significant advance. The research aim is to determine role of soil factors in the development of undergrowth in pine forests in Riga. The results of the research indicate that soil factors which influence undergrowth of pine forest are the amount of exchangeable cations and cation exchange capacity in the $\mathrm{O}$ horizon. 